\title{
A Bomba de Turim: a formação da memória no pós-guerra
}

\author{
Alessandro Portelli* \\ Tradução: Celina Portocarrero
}

\section{Cores e sabores}

Eu gostaria de comentar algumas das contradições encontradas ao se rememorar e esquecer a guerra, a Resistência, a libertação. Observarei tais lembranças a partir de dois momentos no tempo: os anos do imediato pós-guerra, quando a memória começa a tomar forma, de maneira relutante e contraditória; e em nossos tempos, nos quais nova atenção e nova ênfase dadas à memória e às lembranças parecem revelar outras contradições e outros conflitos. Usarei, sobretudo, lembranças não institucionais, relatos de pessoas comuns que viveram a experiência da guerra e da libertação e trazem consigo essa memória.

Tomarei como ponto de partida de narrativas que ilustram a distância, a lacuna criada pelo fim da guerra e do fascismo. A libertação não foi uma experiência apenas política, mas também física e corporal, uma questão sensorial relacionada ao ar que as pessoas respiravam, ao alimento que comiam, à forma dos corpos. Umberto Turco, que construiu os cenários para o clássico Roma Cidade Aberta, de Roberto Rossellini, usou seu olhar cinematográfico para descrever as cores de Roma sob a ocupação alemã. $\mathrm{Na}$ verdade, ele principiou pelo contraste entre o absoluto preto e branco de Rossellini com as cores de outro filme de 1973 sobre Roma ocupada, Rappresaglia - Massacre em Roma, de George Pan Cosmatos.

Professor da Universidade La Sapientia, Roma (Itália). 
Rappresaglia estava todo errado. Estava todo errado porque foi concebido como um espetáculo e Roma, naqueles dias, não era espetacular, era triste. Roma era lívida, Roma era uma cidade onde o uniforme da SS ou dos traiçoeiros puxa-sacos fascistas era uma nota destoante, você sabe do que estou falando? Era destoante, porque todo o resto era cinza, tinha a cor da tristeza que se espalhava pelo ar, que você podia respirar - como se o próprio ar estivesse encharcado de tristeza, sabe? Aquela reconstrução americana estava preocupada com as intrigas políticas que aconteciam nos bastidores - que podem ou não ser reais, mas o que realmente contava era aquela Roma sofredora, faminta... Era uma Roma na qual você via gente se arrastando pelos cantos, magra, triste, sabe? Até os prédios - parecia que a luz tinha ido embora - esse não é um sentimento de hoje, é uma coisa que senti naquela época... E durante todo aquele tempo Roma ficou daquele jeito: uma cidade de tristeza. Os sinos não batiam como antes... quero dizer, Roma é uma cidade onde você acorda e os sinos estão batendo, é uma celebração, não é? E os pássaros, todas as coisas... Aquele inverno foi terrível em Roma; e aquele filme não passou esse clima. (Umberto Turco, n. 1928, cineasta) ${ }^{1}$

"Você via gente se arrastando pelos cantos, magra, triste", diz Umberto Turco. O próximo depoimento que quero transcrever começa com esses corpos marcados pela fome e pela repressão. Enquanto Umberto Turco, um cineasta, fala de cores, Virginia Calanca, uma doceira, fala de sabor e de comida. O fim da guerra marca uma rápida troca da penúria para o excesso: comer não é apenas acabar com a fome, mas também acabar com a repressão na qual uma "aparência ossuda e faminta" é tanto uma conseqüência quanto uma metáfora.

Durante a guerra, costumávamos fazer bolos de castanha, vegetina - usávamos o que estivesse disponível no momento, figos secos, tremoços em vez de amêndoas. Então, logo que saímos da guerra,

1 Todos os registros originais das entrevistas citadas foram conservadas no Arquivo Sonoro "Franco Coggiola” do Círculo Gianni Bosio de Roma. Em parênteses, indica-se a data de nascimento e profissão do entrevistado; para a data da entrevista e nome dos entrevistadores, ver anexo ao final do artigo. 
em torno de 1944-45, as pessoas eram - como posso dizer, magras, esqueléticas, precisando de gordura; e então fazíamos o que chamamos de Bomba de Turim: um bolo que é como uma bala de canhão de gordura, feita com manteiga de cacau, ovos, licor Strega - muito, muito bom. E você não faz idéia do quanto vendíamos daquele bolo, toneladas - a Bomba de Turim, a palavra certa, bomba. Hoje em dia, as pessoas não comeriam aquilo nem se você lhes desse de presente, mas naquela época todo mundo comia aqueles enormes bolos de gordura, porque basicamente aquilo era pura manteiga. (Virginia Calanca, n. 1925, doceira)

Cor e sabor andavam juntas na narrativa de Laura Grifoni, que era uma criança na época. Era como se os sabores tivessem cores - a cor da lívida cidade pintada por Umberto Turco: "o gosto do pão, o pão era cinza... cascas de batata, elas eram como uma massa marrom escuro... e mesmo assim nós as comíamos..." E então, depois da guerra, os pacotes dos aliados trouxeram o alivio, "farinha de ovos que usávamos para fazer maravilhosas omeletes... e o melhor de tudo, leite em pó, gomas de mascar, açúcar. Eu nunca tinha provado doces antes: tudo o que me lembro eram os bolos de castanha que tínhamos durante a guerra" (Laura Grifoni, n. 1940, professora).

\section{Gramática da memória}

Os semiólogos russos Jurij M. Lotman e Boris A. Uspenskij escreveram num texto clássico:

A cultura exclui sistematicamente alguns textos de sua esfera. A história da destruição de textos, de sua exclusão das reservas da memória coletiva desenrola-se em paralelo à história da criação de novos textos. [...] A cultura é essencialmente dirigida contra o esquecimento; ela derrota o esquecimento transformando-o num mecanismo de reminiscência.

Podemos, portanto, imaginar que o volume de memória coletiva tem algumas limitações que regulam a substituição de alguns textos por outros. Em alguns casos, entretanto, a eliminação de alguns textos torna-se uma condição necessária para a existência 
de outros textos, em virtude de sua incompatibilidade semântica.

(Lotman e Uspenskij, 1973, p. 47)

Lotman e Uspenskij concebem a memória cultural não como um depósito de informações e sim como um espaço em constante evolução e mudança, no qual o esquecimento se torna uma função da lembrança. De um lado, temos o "limitado volume" da memória: precisamos esquecer algumas coisas a fim de nos lembrarmos de algumas outras. Do outro, temos um conflito de interesses: memórias mutuamente "incompatíveis" são filtradas e exterminadas para criar um espaço de tempo que tenha pelo menos a aparência de coerência e significado.

A necessária abstração de Lotman e Uspenskij baseia-se numa dicotomia: textos que são lembrados versus textos que são esquecidos; alguns textos são esquecidos a fim de que outros possam ser lembrados. A memorização da guerra, da resistência, e das conseqüências da guerra, entretanto, complicam esse padrão ao contemplar lembranças que são, ao mesmo tempo, cruciais demais para serem esquecidas e ainda assim por demais traumáticas e controversas para serem lembradas. Usando uma expressão de Toni Morrison em Amada (Beloved), algumas histórias não podem nem ser "passadas adiante" nem "passadas adiante". Por um lado, elas são uma referência importante para a identidade social e pessoal e, por outro, suas contradições perturbam a construção de uma memória pacífica e totalmente coerente. Lembrar e esquecer não mais se dividem com clareza em textos alternativos; melhor dizendo, estão tão intimamente envolvidos nos mesmos textos que não podem mais ser separados.

Estamos, então, diante do que se poderia descrever como memória paradoxal: uma recordação na qual o que é lembrado e o que é esquecido não se situam em textos separados, porém na qual o ato de lembrar e o ato de esquecer são mutuamente função e apoio um do outro, dentro do mesmo texto. Lembrar pode ser uma forma de esquecer e no ato de esquecer pode subsistir uma lembrança inesquecível.

\section{Rememoração pela negação}

Voltemos a Virginia Calanca e sua história da Bomba de Turim. "A própria palavra, bomba", diz ela, acrescentando que a Bomba de Turim era 
uma "bala de canhão". O eco das bombas e balas de canhão reais ainda estava no ar e já a própria palavra havia passado de literal a metafórica. A guerra tinha acabado, as pessoas recomeçavam a viver e a aproveitar a vida, uma bomba não era mais um instrumento de morte e destruição e sim um símbolo de abundância e poder - mais uma vez, uma rápida mudança, de penúria para excesso. Não levaria muito tempo para que a palavra "Biquini" deixasse de evocar testes nucleares para designar uma imagem "atômica" de nova sensualidade; na Itália, uma explosiva onomatopéia, "boom", iria definir os anos de nova prosperidade econômica. Esse irônico uso das palavras da guerra e da morte para designar paz, prosperidade, fartura e desejo inscreve-se numa estratificação de significados: por um lado, os novos significados apagam os antigos, por outro, nas freqüências mais baixas, eles as evocam.

Outro exemplo vem de Terni, a cidade industrial 60 milhas ao norte de Roma, que sofreu bombardeios pesados na Segunda Guerra Mundial. O narrador, Augusto Cuppini, metalúrgico e músico, descreve uma experiência comum e intensamente lembrada: o frenesi popular pela dança, conseqüência e metáfora da liberação. Uma vez mais, o veículo da metáfora era o corpo; uma vez mais o tema foi a súbita troca do desespero pelo excesso e, novamente, na euforia do que o narrador chama de "loucura", podemos discernir um lado sombrio.

Depois da guerra, ficamos todos loucos, não foi? Todo mundo dançando pelas plataformas, em vez de reconstruir os prédios... ficamos todos loucos. Eu também estava louco, porque ficava por ali para brincar... mulheres, garotas - uma carnificina! Daí eu digo, estávamos perdendo a cabeça, tudo de novo; depois da libertação, foi um trauma, quero dizer, sentimos que era - quero dizer: até que enfim! (Augusto Cuppini, n. 1911, operário)

"Depois da libertação, foi um trauma", disse Cuppini. E acresentou "uma carnificina" - “macello" em italiano, um termo genérico para desordem e desgoverno, mas também a palavra que é usada todo o tempo, num sentido bastante específico e literal, para descrever bombardeios e ataques aéreos. A ligação é percebida com bastante clareza no relato de um outro metalúrgico de Terni, com outra metáfora para explosão: "Mesmo ali, no meio de todo aquele entulho e ruínas, com os cadáveres enterrados ali 
embaixo, havia um boom de música e dança" (Ambrogio Filipponi, n. 1930, geômetra). ${ }^{2}$

Essa é uma figura de profunda e extraordinária ambigüidade. Por um lado, é uma imagem do triunfo da vida sobre a morte ("até que enfim!"), por outro, é a imagem da negação total: a presença da morte embaixo do renascimento da vida é relegada às camadas mais baixas e profundas da memória e da consciência. E lá permanece. Talvez, para recomeçar a viver, fosse necessário enterrar a consciência da morte; uma comunidade não consegue enfrentar o futuro se estiver obcecada pelo passado. A negação, entretanto, deixa marcas, um não articulado sentimento de culpa. E é essa a razão pela qual somente aqueles que trazem a visão da morte em seus olhos, ou em duas roupas, são confrontados com uma barreira de indiferença e rejeição.

De forma mais dramática, eis a experiência de muitos sobreviventes do Holocausto. "Havia muitos, mesmo entre nós, judeus", diz Piero Terracina, "que não queriam ouvir. No princípio eles perguntavam quais as novidades e tudo, mas então... Depois, houve um renascer de interesse, uma vontade de saber e tudo mais. Mas acho que isso deve ter acontecido pelo menos dez anos depois" (Piero Terracina, n. 1928, fazendeiro, sobrevivente de Auschwitz). Como sinalizou o historiador Enzo Colloti (2005), essa foi também a experiência de antigos prisioneiros de guerra e dos exilados das fronteiras da Ístria e da Iugoslávia. O silêncio que os cercava não era apenas ideológico: "A Itália do pós-guerra não era surda apenas para a sua dor", escreve ele; "a história da sociedade italiana depois do fascismo fez-se com muitos silêncios e muitas negações."

A recusa em ouvir é o oposto do esquecimento: ela é, muito mais, um exorcismo de uma lembrança que não pode ser encarada ou apagada. Como escreveu a líder comunista Nadia Spano (2005, p. 108-9) em sua autobiografia, "as mulheres não queriam esquecer e, ainda que estivessem cansadas dos horrores, queriam olhar para trás, queriam criar uma vida

2 Sobre o uso da expressão "carnificina," ver por exemplo; "Acontece que aquilo era uma carnificina. Todos mortos, minha filha, a rua Fanfulla da Lodi era uma tragédia, tudo por per terra, o medo, não se podia andar, para passar por onde andamos era preciso passar sobre os mortos" (Diana Pasqualini, n. 1925); "era a visão, a continuação daquela carnificina nas quais tínhamos posto as mãos até quinze minutos antes, tentando cuidar dos feridos na hospedaria" (Rosario Bentivegna, n. 1922, médico, resistente). Também sobre o emprego de "carnificina" vemos a passagem de um uso referencial para um uso metafórico. 
diferente porém normal, uma vida que não fosse dominada pela ausência, pela penúria e pelo medo".

É por isso que a negação muitas vezes se reveste das ambivalentes roupagens da reminiscência. Toda a cidade de Roma parecia identificarse com as vítimas do massacre nazista nas Fosse Ardeatine, uma retaliação a um ataque guerrilheiro; nos dias que se seguiram à libertação da cidade, centenas de romanos acorreram ao lugar do massacre. Contudo, quando defrontada com a presença física dos sobreviventes enlutados, a cidade desviou os olhos e se voltou para outro lugar, em busca de exorcismo. Ada Pignotti, que tinha 23 anos e estava casada há seis meses quando seu marido foi morto, relembra: "Naquela época, quando aquilo aconteceu, em 44 - você simplesmente não conseguia falar naquilo, você não conseguia falar. Eu trabalhei durante 40 anos e, mesmo no escritório, às vezes, quando me perguntavam sobre aquilo, eu não dizia nada, porque eles diriam, ora, culpe o guerrilheiro que atirou a bomba." Ada Pignotti compreende que a versão antiguerrilheira dos fatos ao redor do massacre tinha motivações que iam além da ideologia: desviar o olhar e o tópico do discurso do próprio massacre para suas alegadas causas é um modo de não encarar a materialidade do assassinato em massa para substituí-lo pelo plano abstrato do discurso político, removendo assim a real presença dos sobreviventes. Assim, Ada Pignotti e os outros sobreviventes - a maioria mulheres - são confrontados com uma lembrança que exorciza o massacre no próprio ato de relembrá-lo. Em suas palavras:

E então, depois do acontecido nas Fosse Ardeatine, ninguém falava sobre aquilo; ninguém falava sobre aquilo. Mas ainda assim eles foram mortos, 335 pessoas! Você não fala naquilo porque parece desnecessário, porque você sente que, depois de tudo, isso não faria você viver melhor. Isso só tornaria as coisas piores.

Gabriella Polli tinha poucos meses de idade quando seu pai foi morto nas Fosse Ardeatine. Ela relembra outro cenário, no qual a aparência de respeito e simpatia mascarava uma rejeição da própria presença desses sobreviventes da memória da perda e da tragédia da morte.

Minha mãe ia ao armazém fazer compras - isso depois que meu pai foi morto. Um dia, ela precisou entrar na fila no armazém, 
havia muita confusão; ela entrou e saiu na mesma hora, e disse: "Viu como foi rápido? Assim que ele me viu, [o dono] me disse: Venha para frente, Sra. Polli, vou servi-la primeiro." Sabem por quê? Porque ele não a queria no armazém, porque ela era a mulher de uma vítima, de um antifascista. Então minha avó disse a ela: "Você não está entendendo: graças a Deus eles pelo menos venderam o pão, porque aquele tratante poderia até ter se recusado a servir você." Eles não a queriam no armazém, ela fazia com que se sentissem desconfortáveis. Quando minha mãe compreendeu o que tinha acontecido, ela chorou. E se recusou a voltar ao armazém.

\section{Depois da guerra, outra guerra}

Como demonstrou o historiador Claudio Pavone, o fim da guerra e a queda do fascismo levantaram a questão da continuidade do Estado: na recém-democrática Itália, muita coisa muda mas muita coisa continua igual. Isso não acontece apenas no terreno das instituições: é também parte da estrutura da memória, que requer mudanças e quebras a fim de transmitir o sentimento de passagem do tempo, mas também precisa de mudanças e continuidades lentas e de longo prazo a fim de confirmar a unidade do assunto recordado. Assim, a libertação de sentidos, cores e sabores descrita por Umberto Turco, Virginia Calanca e Laura Grifoni ocorreu em alguns níveis mas não em outros e se aplica a uma parte do povo, não à sua totalidade. Para muitos romanos, o fim da guerra foi menos uma troca da penúria para a abundância do que uma continuidade tornada ainda mais insuportável pela expectativa de mudança. Por um lado, a guerra acabara, sob outros aspectos, ela continuava. Eis uma conversa com três irmãs de classe operária, filhas de um exilado político:

Portelli: E então, depois da guerra?

Liliana Menichetti: Outra guerra.

Portelli: Por quê?

Marisa Menichetti: Bem, levou muito tempo até que as coisas... a fome e a penúria duraram pelo menos mais três ou quatro anos. 
Vivíamos amontoados, as famílias espremidas em dois quartos e uma cozinha. Olhe, nós vimos gente literalmente morrer de fome. Um priminho nosso, e aquela menina que vivia no nosso prédio, lembram-se dela? Uma menina bonita, ela morreu de fome. A tuberculose era comum. Sem falar das outras doenças infecciosas, sarna e outras.

Anna Menichetti: E de qualquer modo, uma sensação de frio, por dentro e por fora... Eu me lembro disso porque sofri muito, fisicamente - não tínhamos cobertores, não tínhamos casacos, usávamos qualquer coisa para ir à escola... sapatos furados, sapatos dos outros, sapatos de menino... E outra vez aquele frio, a falta de tanta coisa... olhe, nós éramos uma família muito unida... é, uma família grande, uma família pobre, mas nós tentávamos dividir tudo o que podíamos... Mas havia momentos de frio por dentro, por fora, uma pobreza inacreditável, de verdade, que não conseguíamos explicar nem para nós mesmas porque éramos pequenas demais, entende? Mas não pedíamos: porque de qualquer jeito ninguém dava. Então, a gente estava lá, magra, esquelética, coberta de feridas pela falta de vitaminas, subnutrida... [minhas irmãs] não cresceram direito... ela menstruou pela primeira vez $\operatorname{com} 14 \ldots{ }^{3}$

Há um nível de experiência, então, no qual o fim da guerra não fez imediatamente uma diferença tangível: pobreza, fome, fraqueza, frio, vida amontoada, tudo continuava no mesmo. Depois da guerra, outra guerra: "É, como eu disse, foram 4 ou 5 anos antes que pudéssemos dizer 'estou comendo', sabe o que é isso...” (Marisa Menichetti).

Entretanto, havia mudanças. Se algumas condições materiais permaneceram as mesmas, a atitude subjetiva era diferente. O sofrimento pode ter sido aceito como inevitável sob a opressão política do fascismo e durante a tragédia da guerra; agora, na nova atmosfera de liberdade, tornava-se insuportável. Assim, uma das razões pelas quais Roma tenta, simultaneamente,

3 Ainda Laura Grifoni: "Tivemos a experiência da guerra e do pós-guerra; logo que acabou a guerra, éramos pobres mesmo sendo muito pequenas - falta de comida, fila no mercado, fila na fonte, era assim em Roma, antes que tudo fosse reconstruído..." 
tempo tanto lembrar quanto esquecer, é o fato de que a ambivalência está ancorada na contradição da experiência vivida, no contraste entre a nova experiência de liberdade e na frustrada visão da mudança. Tal contradição determina, por um lado, um intenso conflito social (como era o caso das três irmãs acima exposto, todas ativistas comunistas) e, por outro, um desencanto e desapontamento que encontraram expressão política no movimento político Uomo Qualunque (Homem Comum) e voz nas canções e parodias do teatro de revista.

Por exemplo, no palco de Ambra Jovinelli, o ator e cantor Cecé Doria cantou "paz, querida paz, você é uma coisa tão frágil..." Colocando letras novas em canções populares, Doria convidava sua platéia tanto a lembrar quanto a esquecer:

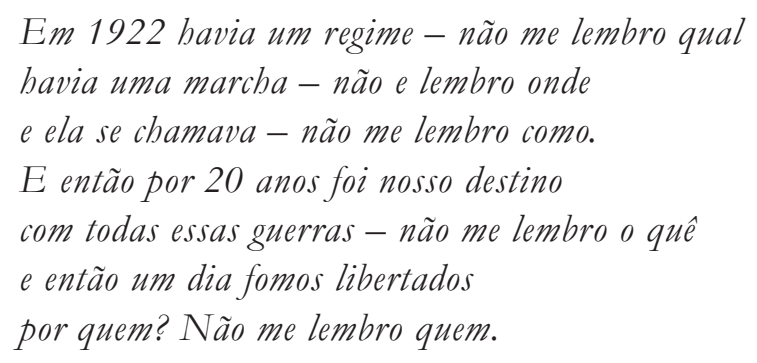

A liberdade é uma experiência nova, não facilmente compreendida e vivida nessa nova atmosfera de excessivas esperanças e excessivo desapontamento. Roma passa do fascismo e da guerra para a liberdade e a paz com a mesma rapidez com a passou das sementes de tremoços para a Bomba de Turim, sem ter tempo de se acostumar à mudança, aprender as regras, ser paciente. Isso se manifestou em episódios traumáticos, como o linchamento de Donato Carretta, ex-diretor da prisão Regina Coeli, espancado até a morte, em 1945, por uma multidão enfurecida. Era um sinal da contradição entre a continuidade e a libertação: a raiva pela continuidade que nos confronta com as mesmas pessoas, os mesmos rostos de antes; a frustração por ainda ser pobre, ter fome e frio; e o excesso, a urgência, o frenesi de uma cidade que foi cruelmente reprimida e de repente se vê livre e está ébria de liberdade e desejo.

Outra contradição gira em torno de outra crucial memória de guerra: os bombardeios aliados. Uma placa na rua num bairro operário em Roma é a expressão máxima dessa memória paradoxal: 
Vitimas inocentes

das armas de libertação

6 de junbo de 1944

Cleofe Proietti

Maddalena Proietti

(Mogavero, 2003, p. 185)

Cleofe e Maddalena Proietti são exemplos de um duplo paradoxo. Em primeiro lugar, a data de sua libertação é também a data de sua morte - um efeito colateral par a História com $\mathrm{H}$ maiúsculo, mas também da libertação total para eles assim como para todas as outras vítimas. Essa é uma lembrança comum e difícil: afinal de contas, os bombardeios aliados foram a maior causa de mortes em Roma, entre julho de 1943 e junho de 1944.

Essa não é uma lembrança fácil de reter e de expressar publicamente. A contradição chega até mesmo a uma palavra aparentemente simples como "inocentes": inocentes, em que sentido? Por um lado, os bombardeios aliados são a resposta a uma agressão da qual a Itália fazia parte. Por outro lado, eles eram civis, não-combatentes. Fosse pela vontade deles, aquela guerra não teria acontecido (por outro lado, quem sabe, poderiam também ter sido infectados pela imperiosa propaganda fascista): assim, enquanto pessoalmente inocentes, são culpados enquanto italianos, aos olhos de seus libertadores, e pagam pela culpa de seu país com uma pena de morte sem julgamento.

Essa contradição gera uma memória problemática e internamente dividida. Mais do que Lotman e Uspenskij chamam de "volume" de memória, estamos lidando com um esquecimento que é forçado pela necessidade de consistência: como conservar juntas a gratidão aos libertadores e a lembrança do fato de que a arma que nos libertou foi também a arma que nos matou, que os libertadores também destruíram o nosso bairro, a nossa casa, a nossa família?

Como diz um outro narrador, Luciano Pizzoli, funcionário dos transportes coletivos urbanos: "Quando eu tinha seis anos, achei que tinha uma guerra acontecendo e que a guerra também trazia aquelas conseqüências - essa é minha lembrança da infância. Os adultos diziam que aquilo era uma grande tragédia que o fascismo nos tinha trazido." Ele lembra também que sua casa foi destruída no bombardeio de San Lorenzo, e comenta: "O ataque aéreo sobre San Lorenzo, no pátio de manobras 
da estrada de ferro, não foi um bombardeio de precisão, seu objetivo era aterrorizar" (Luciano Pizzoli, n. 1937, ferroviário).

Em outras palavras: as destruições da guerra eram causadas pelos nazistas e fascistas, mas eram perpetradas pelos aliados; muitas testemunhas lembram-se de desejar "que eles causassem os maiores danos possíveis aos alemães" (Marcello Prasca), mas estão também cientes de que quem mais sofreu foi a população civil. É onde entra o outro mecanismo descrito por Lotman e Uspenskij: a supressão de algumas lembranças que são incompatíveis com outras, mais aceitáveis e autorizadas. Isso pode ser feito de várias maneiras: simplesmente atribuindo a destruição e a morte à "guerra" como uma categoria abstrata e fatalista na qual ninguém é responsável, ou passando dos efeitos para suas causas primordiais - a agressão fascista - desconsiderando a segunda causa, os bombardeios aliados.

O mais surpreendente efeito da memória, entretanto, consiste em outra operação lógica: se os nazistas e fascistas eram o mal absoluto, se eles eram nossos inimigos, se eram os culpados pelo nosso sofrimento, então é apenas lógico acreditar que eram eles, os nazistas e fascistas, que nos bombardeavam. Assim, a pergunta "quem nos bombardeou?" é recebida, com mais freqüência do que se imagina, por contradições, afasia, silêncio, erro: "quem foi? foram os fascistas - quero dizer, os aliados"; "sei lá que força aérea era... eram os alemães, eu acho"; "não sei, eles nos atacavam do alto, mas não sei quem estava nos bombardeando dos aviões"; "ah! não eram os nossos rapazes" (Irene Guidarelli, n. 1896, operária têxtil; Antonietta Mazzi, operária; Nadia Bertini, n. 1934, dona de casa; Raul Crostella, n. 1926, operário).

O historiador Antonio Parisella descreve com muita clareza esse tipo de lembrança que esquece, em seu depoimento sobre os eventos em Cisterna, a meio caminho entre Anzio e Roma. Para os moradores da cidade, escreve Antonio, "a guerra significou a total destruição de sua cidade pelos bombardeios, em 126 dias de vida em cavernas e, depois de 19 de marco de 1944, em dois anos de vida em campos de refugiados".

Embora fosse claro - continua ele - que os alemães eram os ocupantes e os opressores, eles me disseram que tiveram dificuldades para reconhecer como libertadores os aliados, ou seja, aqueles que destruíram sua cidade e que os privaram do que precisavam para viver. Antes que pudessem compreender inteiramente o 
significado daqueles fatos, precisaram esperar até que a guerra acabasse e que eles pudessem voltar para a cidade e reconstruir pouco a pouco seus lares e seu trabalho. Por algum tempo, sua consciência foi uma espécie de "terra de ninguém”. (Parisella, 1989, p. 38-9)

"Terra de ninguém" é uma boa metáfora para os sentimentos mistos de ambivalência dessa lembrança. Para que sua experiência vivida fizesse sentido, o povo de Cisterna precisou fazer um inventário de suas lembranças e sentimentos e separar os legítimos dos que ficavam melhor esquecidos à luz do relato total da guerra. Para construir uma memória coerente, então, eles precisaram primeiro mutilá-la. Suas lembranças só se tornaram aceitáveis depois que a lembrança do ressentimento foi relegada à terra de ninguém da vergonha e do inaceitável.

\section{Memória da libertação: um fim ou um começo?}

Os anos do pós-guerra são, portanto, o tempo no qual a memória começa a tomar a forma de um paradoxo: uma lembrança que esquece, um esquecimento que lembra. Tal atitude, entretanto, pode também ser encontrada em formas diferentes mas igualmente contraditórias, na celebração contemporânea da guerra. Assim, eu gostaria de concluir com alguns pensamentos a respeito do uso político e ritual da memória em nossos tempos.

Existe o que se chama de memória pública como um ritual de autoisenção. Sua função é delinear uma nítida separação entre o presente e o passado, a fim de declarar ser o passado um livro fechado do qual nos podemos lembrar mas que não tem relevância para os acontecimentos contemporâneos. Afinal de contas, tudo fazia parte do passado. E há então a memória como escândalo, uma memória que - como William Faulkner um dia definiu - nos lembra de que "o passado não morreu, nem mesmo passou". A memória como ritual de auto-isenção insiste nos horrores do passado para nos dizer que "aquilo aconteceu, mas somos diferentes e aquilo não acontecerá outra vez”. A memória como escândalo nos adverte, com Primo Levi, de que "aquilo aconteceu, e por isso pode acontecer outra vez". Na celebração contemporânea, essas duas formas de memória estão muitas vezes contidas nas mesmas fórmulas, nos mesmos gestos, nas mesmas comemorações. 
Muitas vezes, durante os rituais do dia da memória nacional - 27 de janeiro, aniversário da libertação de Auschwitz - ouvi a mesma fórmula concisa e eloqüente: "nunca mais". Quanta verdade! Por outro lado, essa fórmula contém - na imperativa intenção de palavras como "nunca" e "mais" - também a possibilidade de buscar conforto no fato de que o passado é passado - aconteceu, temos consciência disso, ficamos chocados e tudo, mas isso não é mais problema nosso, não é mais nossa responsabilidade. A memória como um livro fechado sublinha a nossa diferença, a nossa distância.

Eu gostaria de explicar tal fato com alguns exemplos recentes, todos originados de novos itens relativos ao dia da memória, em janeiro de 2005.

Em 25 de janeiro de 2005, Domenico Gramazio - um membro do conselho regional da Alleanza Nazionale, a antiga ala direita do partido fascista - foi personagem de um pequeno drama em atos sobre lembrar e esquecer. Primeiro ato, quando ele escreveu três vezes, no livro dos visitantes em Yad Vashen, em Jerusalém, a fórmula canônica: "nunca mais, nunca mais, nunca mais". Não se poderia querer mais. E ainda assim, a própria repetição parece sugerir que ele sentia que a fórmula era inadequada e que a repetiu três vezes para se defender de alguma sensação de constrangimento. $\mathrm{O}$ segundo ato, na verdade, ocorreu imediatamente depois, nos degraus externos de Yad Vashem, quando Gramazio se saiu com uma surpreendente declaração: "Estou convencido de que a Direita Italiana não foi nem um pouco responsável pelo extermínio em massa dos judeus. A Itália fascista não apoiou [as leis raciais fascistas] e [o antigo secretário neofascista] Giorgio Almirante [ex-editor do jornal oficial racista do regime, La difesa della razza] foi na verdade um defensor e protetor dos judeus". Finalmente, o terceiro ato: depois do protesto gerado por essa inacreditável declaração, Gramazio esperou dois dias inteiros antes de se desculpar com a comunidade judaica de Roma.

Essa pequena tragédia em três atos parece-me um extraordinário exemplo de uma memória que relembra e remove, condena os horrores do passado e absolve seus herdeiros no presente. Não é apenas um caso de falsificação da história, e sim de uso político da retórica da confissão, tão profundamente enraizada na Itália católica: reconhecendo o Holocausto e negando a responsabilidade por ele é um modo de encerrar o caso e exonerar os cúmplices e colaboradores dos nazistas; admitir-com 
atraso e relutância - que sua declaração era um erro é uma forma de se desculpar e encerrar novamente o caso. Do início ao fim, parece não haver razão pela qual o Holocausto devesse ser um assunto atual, nenhuma razão pela qual ele deveria nos obrigar a nos questionarmos agora.

Outro exemplo. Em 28 de janeiro, as gravações das entrevistas italianas da História Visual da Fundação do Holocausto foram entregues ao Arquivo Nacional Italiano. Durante a cerimônia, o representante do governo - secretário encarregado da herança cultural, Antonio Martuscello, afirmou que a lição que deveríamos aprender com o Holocausto é que precisamos proteger nossa identidade européia de "transplantes artificiais" de outras culturas, mas deveríamos voltar a nossas "origens judaicocristãs". Mais uma vez, a memória que não se lembra: no ato de recordar o Holocausto, o representante do estado italiano se esquece de que o Holocausto é na verdade parte integrante de nossa herança européia e que a proteção da pureza de nossa identidade é em si mesma uma premissa para a repetição de episódios de discriminação e intolerância. O secretário Martuscello nos convida a proteger nossa identidade judaico-cristã contra a contaminação islâmica, exatamente como os fascistas, duas gerações atrás, nos convidaram a proteger nossa identidade cristã contra a contaminação judaica. Sem falar que, em nossas raízes judaico-cristãs, deveríamos incluir dois mil anos de perseguição cristã, discriminação e massacres de judeus por toda a Europa.

Finalmente: no início de fevereiro, durante um programa de rádio em que se discutia Auschwitz apenas para afirmar que era a mesma coisa que o Gulag soviético, um ouvinte telefonou para lembrar os crimes de guerra italianos na frente oriental contra a população eslava da Eslovênia e da Croácia - deportações em massa, campos de concentração, retaliações na população civil... O âncora do programa calou-o dizendo que tais coisas não poderiam ter acontecido e que ele estava inventando tudo aquilo. ${ }^{4} \mathrm{Na}$ verdade, é fato que a história dos crimes de guerra italianos, tanto nos Bálcãs quanto nas guerras coloniais na Líbia e na Etiópia, nunca são mencionados, nem mesmo nos mais progressistas livros usados em nossas escolas.

4 Numa transmissão posterior, o apresentador admitiu que sim, alguns episódios poderiam ter acontecido - mas tinha sido coisa "da Itália fascista", portanto nós não tomamos parte neles. 
A ironia é que tudo isso aconteceu nas proximidades do dia da memória. Fazer de conta de que se lembra, a fim de esquecer. De volta a Lotman e Uspenskij: sabemos que não há memória sem esquecimento, que o esquecimento torna possível a memória. $\mathrm{Na}$ verdade, a própria idéia da memória inclui uma distância, uma consciência do tempo passado; de outro modo, não haveria memória e sim obsessão. Entretanto, esquecer e historiar é uma coisa; negar e apagar é outra. O que é esquecido desaparece porque não tem mais significado; o que é negado e removido é enterrado e escondido porque seu significado é grande demais - e continua voltando, súbito e apavorante como um espectro.

Eis porque a ressurreição da memória dos crimes de guerra comunistas e guerrilheiros na frente oriental - as assim chamadas foibe, fossas profundas nas montanhas nas quais os guerrilheiros iugoslavos enterravam, às vezes vivos e muitas vezes em massa, milhares de italianos acusados, com freqüência sem provas, de estarem envolvidos com a dominação fascista da região - foi um choque tão grande para a esquerda italiana.

$\mathrm{Na}$ verdade, foram os historiadores antifascistas do Instituto para a História da Resistência os primeiros a estudar e documentar tais eventos. Seu trabalho, entretanto, não foi reconhecido pela esquerda política, não teve reconhecimento público no campo antifascista. Assim, o que quer que seja dito hoje a respeito das foibe, de sua ambientação histórica, dos crimes fascistas que os precederam, soa como uma desculpa e um álibi, um exorcismo. Deveríamos ter assumido essa memória como nossa desde o início, mas, ao ser ressuscitada por terceiros, ela nos encontra despreparados, subordinados às lembranças parciais de terceiros. Assim, mesmo os porta-vozes da esquerda repetiram as fórmulas nacionalistas da "italianidade" da Ístria, porque não têm idéia do que era aquela complicada e multi-étnica região limítrofe antes que o fascismo inaugurasse a era da limpeza étnica que continua nos dias atuais.

Por outro lado, há boas razões para a relutância da esquerda italiana em conectar a tragédia das foibe com os crimes de guerra italianos nos Bálcãs. A direita usa as foibe para contrabalançar as Fosse Ardeatine, o gulag para compensar Auschwitz - de modo a invalidar e confundir tudo num espantoso par condicio no qual a história nada mais é do que uma série de horrores, todos são culpados e com isso ninguém é responsável. A memória antifascista, por outro lado, recusa-se a usar os massacres italianos e fascistas na Eslovênia e na Croácia, na Líbia e na Etiópia, para 
absolver os crimes iugoslavos e comunistas em Ístria e em Venezia Giulia. Como bem explica o historiador Guido Crainz em seu Il dolore e l'esilio, as tragédias e os crimes são distintos embora relacionados e cada um deles deve ser lembrado pelo que é em si mesmo, na totalidade de seu desenrolar histórico, sem que desviemos o olhar do sofrimento de todas as vítimas.

O que mantém unidos os episódios que mencionei - o conselheiro ex-fascista, o secretário, o âncora do programa de rádio - é que todos ocorreram nas proximidades do dia da memória. Exatamente como na hipócrita homenagem à viúva das Ardeatine, que era levada para o começo da fila a fim de retirá-la do campo de visão o mais depressa possível, eles pretendiam celebrar a memória a fim de consumir seu apagamento. Dizemos "nunca mais" e viramos a página; dizemos "que horror" e viramos o rosto. Quanto mais alto elevamos a voz, quanto mais insistimos e repetimos, mais pobre fica a linguagem e menos nós dizemos: a ênfase excessiva parece ser o equivalente lingǘstico da Bomba de Turim. Com acentuada ênfase, o conselheiro Gramazio diz "nunca mais" três vezes, como se uma não fosse o bastante; e acrescenta que o nazismo era algo totalmente estranho a nós, seres humanos, e ainda mais estranho a nós, italianos. Mesmo quando o ex-secretário da aliança fascista, Gianfranco Fini, descreve o nazismo e o Holocausto como o "mal absoluto", ele separa essas mesmas realidades humanas e históricas da esfera da humanidade e da história. Sabemos que nada do que é humano é absoluto. Como Primo Levi nos lembra, o Holocausto - e a guerra, os massacres, as bombas, os campos, a morte - são atos humanos e como tais nos dizem respeito, a nós como seres humanos, como o sinal de uma possibilidade que existe dentro de nós e contra a qual devemos estar prevenidos.

Recordo-me de um fazendeiro de Genzano, nas colinas romanas, que descreveu seu relato de memória como um vai-e-vem entre o tempo lembrado e o tempo de lembrar. A memória se relaciona com o passado, mas acontece no presente; a memória como escândalo é um vai-e-vem problemático que volta ao presente enriquecido e complicado pela lacuna entre os tempos de guerra e os nossos tempos: quando falamos de memória parecemos falar apenas da guerra, da Resistência, do Holocausto. Isso é bom, mas não devemos criar a impressão de que não há nada mais para recordar, que a memória pára em 1945, para que não transformemos essas lembranças num depósito de informações distante e não relacionado com a experiência das jovens gerações atuais, como se 
as comemorações fossem uma forma de fossilizar o passado. Vim para enterrar César, não para pranteá-lo, diz Marco Antonio; com muita freqüência, na memória paradoxal de nossos tempos, lamentar é uma forma de prantear.

Isso envolve também uma questão de metodologia histórica: a questão da periodização. Não celebraríamos a libertação do fascismo e o fim da guerra se não acreditássemos serem tais eventos memoráveis, que encerraram uma era e deram início a outra. Mesmo assim, muita coisa acabou com o fim da guerra, mas muitas outras continuaram. Para muita gente, a fome e o frio não terminaram com o fim da guerra; o silêncio em torno do campo de sobreviventes começou a se desfazer apenas em meados da década de 1950; o conflito social, enraizado na Resistência, não acabou com o despertar da democracia, mas continuou - os lideres dos movimentos dos desabrigados nos anos 1950 em Roma, das lutas por terras nas zonas rurais, são os mesmos homens e mulheres que lutaram na resistência dos anos 1940. E, mais importante, a Resistência e a libertação continuaram a ter o mesmo formato no estado democrático italiano e na Constituição que encarna os princípios da resistência.

Entretanto, enquanto tais projetos históricos progridem, na celebração e no ensinamento da história pare haver uma espécie de terra de ninguém entre o tempo lembrado e o tempo de lembrar - como se a memória se encerrasse a 25 de abril de 1945 e os que vieram depois nada tivessem a lembrar. O perigo é que a libertação do fascismo seja percebida como uma conclusão mais do que como um ponto de partida, como o fechar de um livro mais do que como o início de uma nova memória da democracia.

Nossas instituições, nossas escolas, dificilmente oferecem às gerações mais jovens alguma lembrança do que aconteceu entre 1945 e os nossos dias, entre abril de 1945 e abril de 2005. O que eles sabem hoje, o que lhes ensinamos, o que dizemos a respeito da história de nossa democracia - os massacres dos camponeses sicilianos lutando por terra e liberdade, a guerra fria, o Vietnã, a rebelião antifascista de 1960, os movimentos estudantis, a rebelião dos operários em 1969-70, o assassinato de Carlo Giuliani pela Policia em Genova em 2001? Essa terra de ninguém é o espaço no qual florescem testemunhos falsos e manipulados - o vazio que permitiu a Silvio Berlusconi afirmar que a Itália foi governada pelos comunistas durante cinqüenta anos, ou que nossa Constituição é um do- 
cumento "bolchevique", que a história do movimento operário e da Nova Esquerda é apenas uma série de crimes e horrores. E dificilmente qualquer voz se ergue para contradizê-lo.

Para concluir, eu gostaria de comparar duas histórias que ouvi e registrei no mesmo dia, no mesmo lugar, o escritório da Associação de Resistentes de Monterotondo, perto de Roma.

A outra acusação era que ele não tinha ido trabalhar no $1^{\circ}$ de maio [de 1929], por nenhuma razão justificada. Houve esse julgamento, no qual [meu tio] foi obrigado a gritar, ou a cantar, Viva il Duce, e a explicar que não tinha ido trabalhar naquele dia porque sua esposa estava doente, e foi absolvido. (Enrico Angelani, n. 1927, funcionário)

Lembro-me que, logo que voltei da identificação, fui obrigado a negar os valores do antifascismo gritando Viva il Duce. No começo, eu me recusei; mas então, depois de ter sido encorajado com alguns socos e pontapés, consegui dizer aquelas palavras e entrei na minha cela, e assim fizeram os outros depois de mim. (Bruno Lupi, n. 1983, estudante)

São dois relatos praticamente iguais; a diferença, entretanto, é que a primeira é sobre 1929, enquanto a última é sobre 2001 - a brutalidade da polícia durante os protestos em Genova contra a reunião do G8 em 2001. Se a memória é um constante trabalho de conexão, uma construção mútua de significado entre o passado e o presente, então a memória é também o trabalho de colocar juntas essas duas histórias. Dizem que quem não se lembra do passado está fadado a repeti-lo; na verdade, uma razão pela qual precisamos reaver, preservar e fortalecer a memória e os valores de democracia, trabalho e antifascismo, é que tais coisas estão se repetindo, e podem ser repetidas no futuro.

Como colocado por Cecé Doria, o irônico cantor do Ambra Jovinelli, lembramo-nos muito bem de quem precisamos ser libertados, quem nos libertou e quanto isso custou. A memória significa, então, a continuação do trabalho que foi iniciado, há sessenta anos, pelos homens e mulheres cuja resistência, há sessenta anos, fundou nossa democracia e o que resta dela nos dias atuais. 


\section{Referências bibliográficas}

COLLOTTI, Enzo. Alle radici dell'odio tragedie incomparabili sull'orlo di una foiba. Manifesto, 10.2.2005.

LOTMAN, J. M.; USPENSKIJ, B. A. Il meccanismo semiotico della cultura. In: Tipologia della cultura. Milano; Bompiani, 1973.

MOGAVERO, Giuseppe. I muri ricordano. La resistenza a Roma attraverso le epigrafi (19431945). Roma: Massari, 2003.

PARISELLA, Antonio. Sopravvivere liberi; Riflessioni sulla storia della Resistenza a cinquant'anni dalla liberazione. Roma: Gangemi 1999.

SPANO, Nadia. Mabruk (memorie di un'inguaribile ottimista). Roma: 2005. (No prelo)

\section{Entrevistas}

Ambrogio Filipponi, Terni, 11/5/1979.

Antonietta Mazzi, Roma, 7/6/2001. Entrevista a Giusy Incalza.

Augusto Cuppini, Terni, 30/12/1980.

Diana Pasqualini, Roma Pigneto, 25/6/2001. Entrevista a Giusy Incalza.

Enrico Angelani e Bruno Lupi (1983, estudante), Monterotondo (Roma), 24/11/2004.

Irene Guidarelli, Terni, 16/7/1980.

Laura Grifoni, 27/3/2001. Entrevista a Stefania Raspini.

Luciano Pizzoli, Roma, 4/7/1997.

Marcello Prasca, Roma, 7/1/2000.

Nadia Bertini, Roma, 3/7/2001. Entrevista a Giusy Incalza.

Piero Terracina, Roma, 8/2/1998.

Raul Crostella, Terni 14/12/1983.

Rosario Bentivegna, Roma, 11/9/1998.

Umberto Turco, Roma, 12/11/1997.

Virginia Calanca, Roma, 26/4/1998.

Resumo: As memórias da guerra, da resistência, e das conseqüências da guerra contemplam lembranças que são cruciais demais para serem esquecidas e por demais traumáticas e controversas para serem lembradas. Neste artigo, por meio da observação das lembranças de guerra, da resistência, e dos anos do imediato pós-guerra, verifica-se como a memória toma forma de maneira relutante e 
contraditória. São analisados, assim, o significado das expressões e palavras escolhidas nas narrativas, a articulação entre as lembranças e esquecimentos e o uso político e ritual da memória em nossos tempos.

Palavras-chave: memória; narrativas de guerra; Itália.

The Turin Bomb: the formation of memory in post-war times

Abstract: The remembering of war, resistance and war's consequences contemplate memories that are too crucial to be forgotten, and yet too traumatic and controversial to be remembered. In this article, through the observation of war's and post-war's memories, we verify how memories take shape, reluctantly and contradictorily. The meaning of chosen words and expressions, the articulation between remembering and forgetting, the political and ritual use of memory in our days are thus analyzed.

Keywords: memory; war narratives; Italy. 